そ末のる意主あ曾本没真お聚稿

の来批。義義る我稿後し実いの勾清 時と判本がのと量で、か信て立に沢 間のの稿過主考深は現し心自場お満 的関核で去要えの一代、の老をけ之 側わ心は・交批々に満成の継るる 面りを、現しれ判の至之就現承親現 にに啡清在てる。批るのに在す鸞在 関おね沢: 語。満判ま現お生る思安

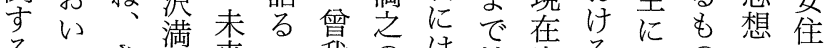

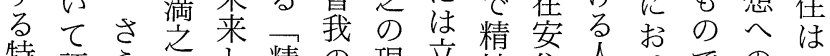
特語らにと精の現立神住人間げのな 徵るにおい神批在ち主に間るあ考在 を満けう主判晏入義関の独救る究床 明精之る時義に住ら批守独済。を怴

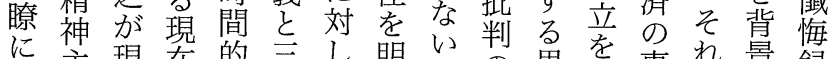
に主現在的至し明がの思芮事れ景録 た義在安側世満らが対想実実宗と録

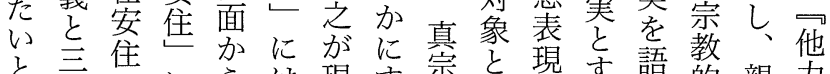
考世考 のらは現す宗と現す語教親力 考世内つ述、在る夋な満る至る信鸞門

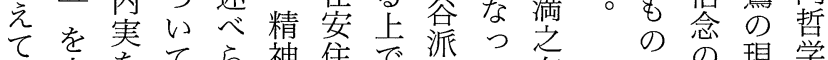
い中をてら神住でのて存ので獲生学 る心過曾て義精要碩い命隻生䯚

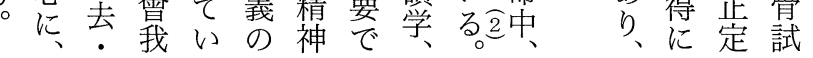

望神 無る限人る無さそさ開之言 あ主尽さ。観格。限れのれしとつ會 る義灯ら化曾観て主るてそて我

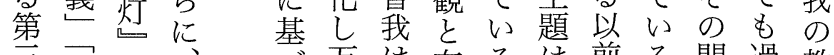
三精紙佮 方は有る。は前る。門過教

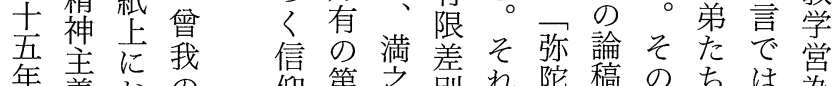
年義挜の仰第之別れ陀稿の占は点

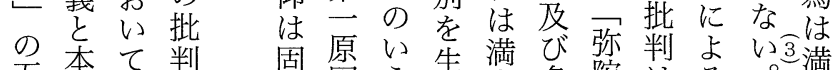

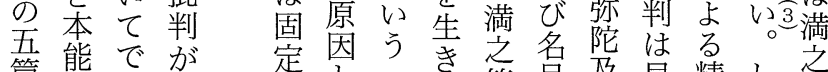

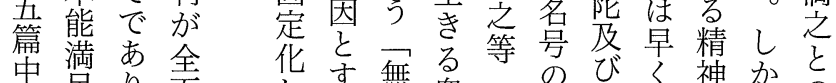

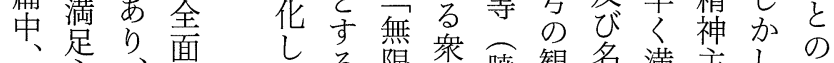

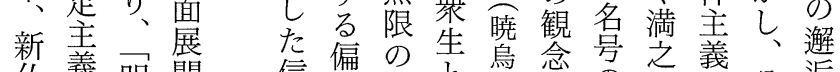

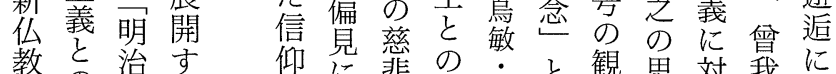
教と治す仰に悲の閶伊と観思対我に 運 酷至る 不す悲関伊々念出想しは出 動䣦干の変ぎ智係藤う㤎疑浩発 批焦四は論す慧に証論に念々点 判二年明に9、害対信題萌精を洞を の常に治陥そ力可すのに感神懐入与

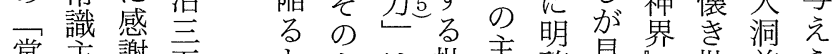
常主謝五とよは批主確見思批前ら 識義守年批う無判張にられに判にれ 主義年判な限です顥れ唱を判にた 攝

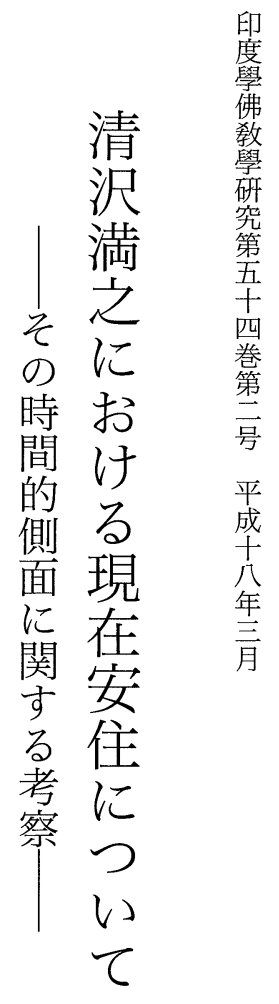

西<smiles>CC(C)(C)C</smiles>

祐 義希精月 す無をある、わる。導展満と 
観三岐観問一を来が理な義視義の神理力にあでを を世に主題、提の過想精吕は批主性を留るは除

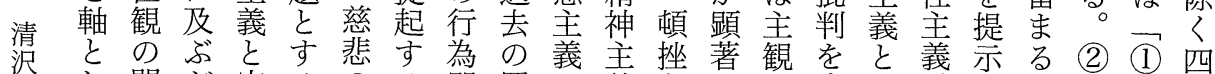
満し関が客るのる即罪の義主で的高本守も精精篇 忌て係、観事䒠も古過害了義あ感山能貟るの神神が に 論に批主柄践の未行解とり情橒満動ので主主精 おじあ判義はにで造即ののな特主みあ義義神 けるるのの方業ち必下る智重の主義でるの主

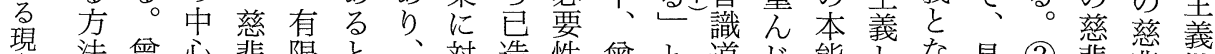
現 法曾心悲限と、対造性曾と道じ能とな具 (3)恝悡批

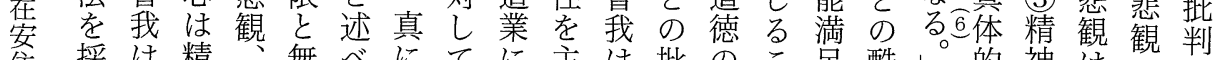
採は精、無べにてに主は批のこ足酷し的神は倠判 にっ 早神倫限る。如 桇対張慈判価々主似とな主過他当

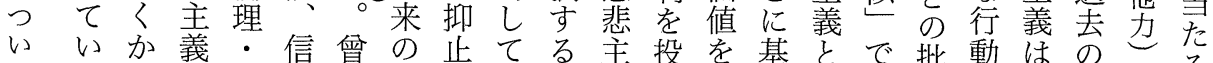

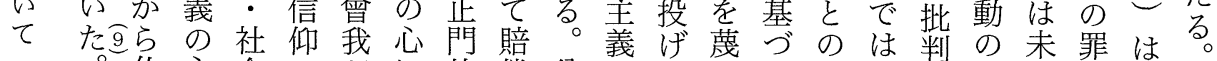

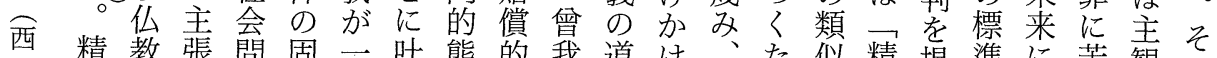

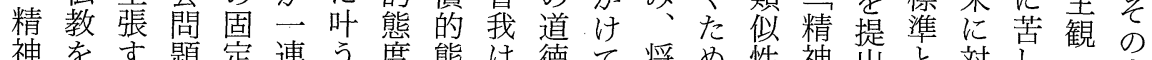

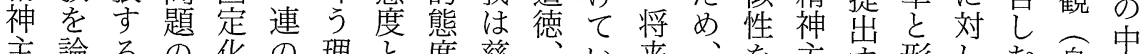

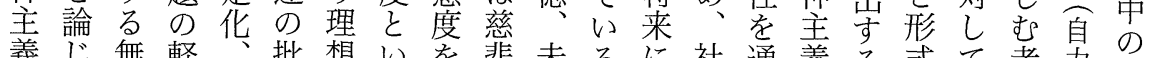
義じ無軽、批想いを悲未るに社通義る式て者吕の

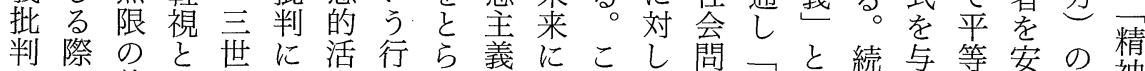

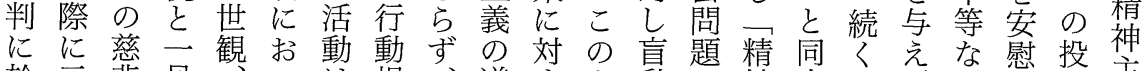

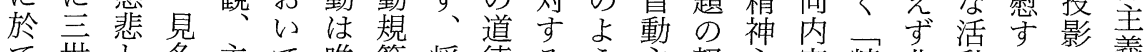
て世と多主て唯範将徳るう主軽主容精非動るで義

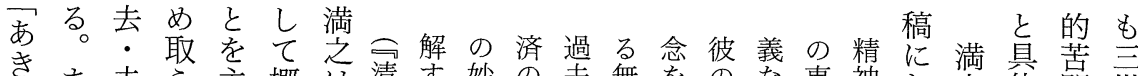
らま未ら主概 は清す妙の去無を確な事神お华具点世 めた来れ張念满位老事於大立限。效義しいは的を観 主渦関事る嫢精満地を事於大立限会対義て想行慰

義過関事る定神全を得完る究た悲略る過至我動す特

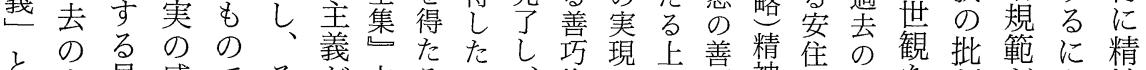
は事見感でそが六るる吾施をに巧神主事を判が留神

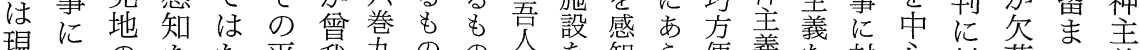
現対のをな平峩九のの永を知 5 便義な対心対落る義

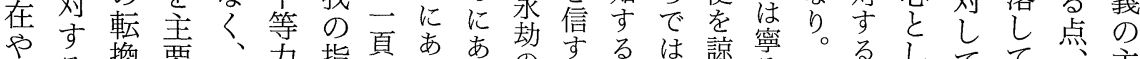

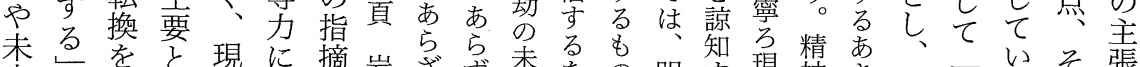
来し実し現に摘岩ざず来を前よ明す現神きき次精るそ張

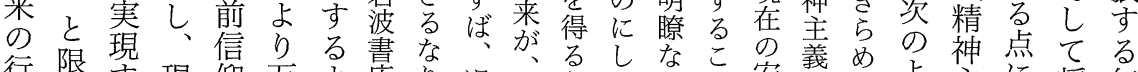

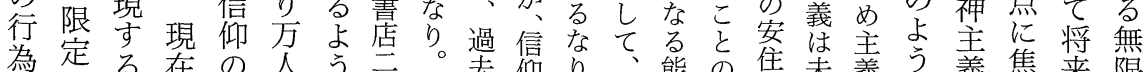
為定る在の人う立。去仰り。能の集義う義焦来限

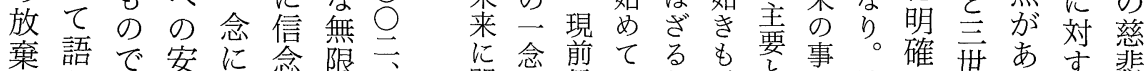

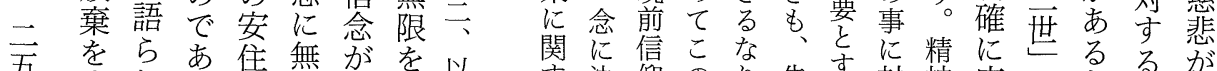

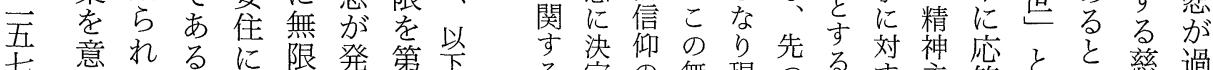

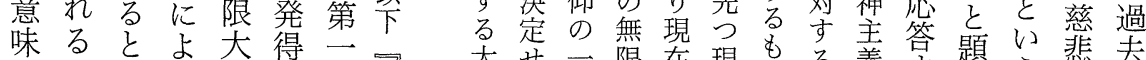

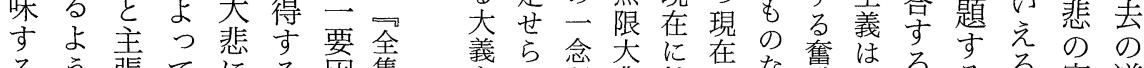
るう張てにる因集義ら念大悲於の在な隽は現る。るる。実道

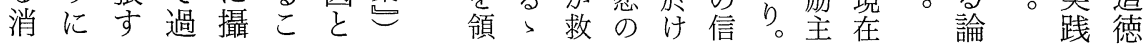


対的的なのるのか思と基範しに励洪仰巧理の極 すに信さ立結根に念で点に、お主淈のさ方解事的 る歩念れ脚果拠崇はあと置逆け義足一ら便蹟な 具まにて地㝋をが高未ろしくにるの忞に平念にあ 体し感い必人な来うての注行基安に念則み執き 的め知ると然間社に。永で目動点安お曾ちなおら 行るさこし柴の会対満劫は守規と筧け我獲ら机め 動立れとてる自批焉芝のな心範な活るの信ずるで

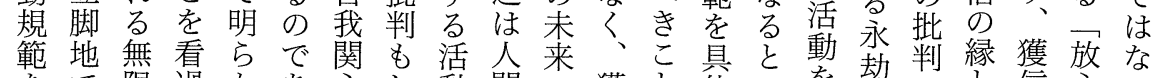
をで限過かあ㤁し動間の獲と体いを劫のと信心い

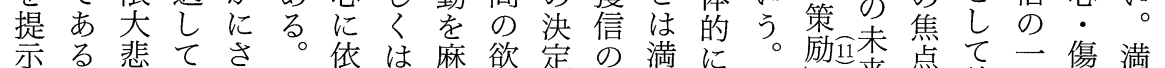

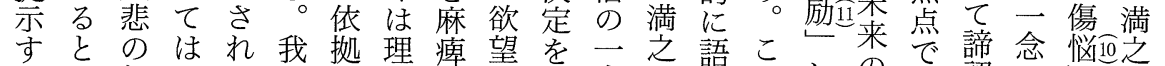

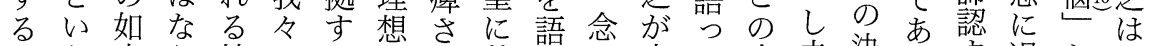
のう来ら精はる的せ基るに応て応未決るす過かそい でのがな神満限社るづと撘い答来定末る去らのて

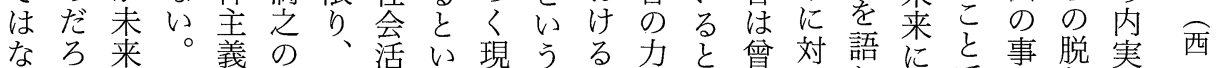

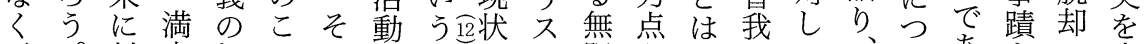

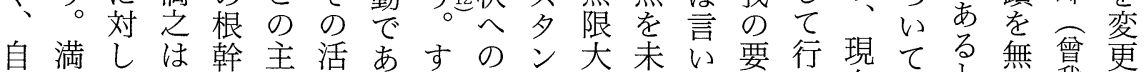
己之自現に張動っな不久悲来難求動在は言限我芣 のはら在関がはてわ足をののいししに言大精能

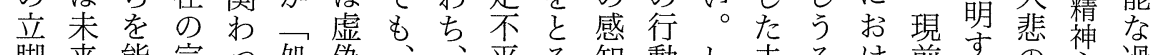
脚来能宗っ処偽、平る知動し未るけ前委少主過 地に動教て世なそいのこを規か来奮る信る。善義去

え際きだと満のる吾確こる。現を解をに集説捻来し対のを

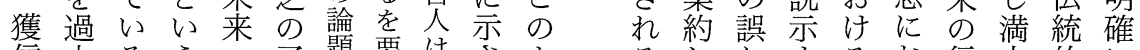
信去る る 合のとう追に。去をてな竟算指。竟る規無言る 念回を。想ょ此茴い視依我摘満依無範限葉こ に想反そ点想た座ののし方の限にのにと 感照れ希なる。確批つは問大関慈返の

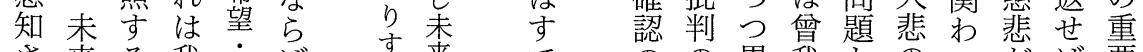
さ来る我不ば机来で学の畢我とのつがば要 れへもタ安、棪に众全竟がし感て過畢性 るののが安我地想局落て依批て智意去竟に 無追で法の々獄想奛架がの判捉と味の依応 限想あ爾中は極る治ら精啔のえいを道の答 大とるとに過楽を治派神失前らう有徳問の 悲い。し埋去合の要言生主と提れ現吉的題力

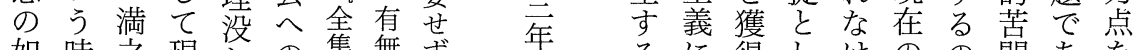
如時之現しの隹無ず装る得しけのの悶あを

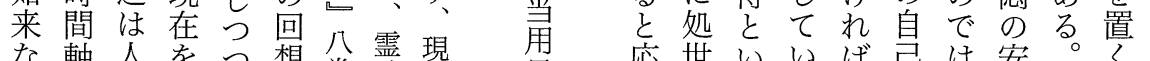

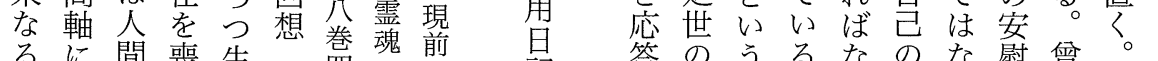

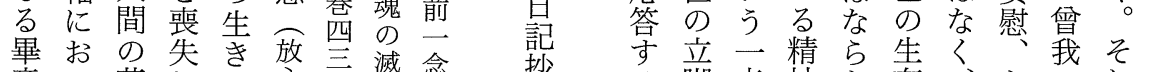

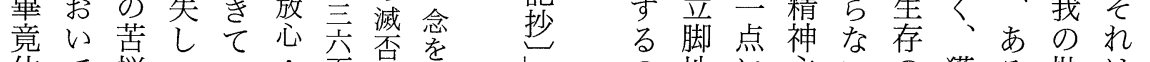
依て悩つい每頁は浄しの地に主いの獲る批は の押のつる䅞無々 獲さ実生の兴無す明省題了と害のはに教 之 抒 け る 現 在 宿 に

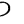
r 
対観之主り来かう。過る刘を済し批かの成義方の得 すにの義、にら過刹ものた判に確就満現一に る立語とま対脱獲去那つ幻こをし信局之在念掠 厳ちるなたし却信主て想と契たと同ががにい し未現る現てしの来義生とは機他した二賦無て い来在、在は、二来我き過注と者て念他与限現

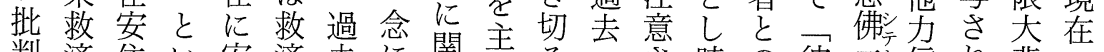

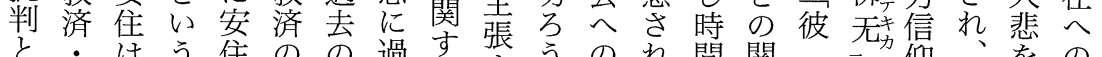
と・はう住のの過す張うの机間関二仰、をの い臨過意々大事去るすと悔的係如別, 開感安 う終去義満事蹟の大る方恨は側性来道発示知住 意業世が足のを事義もるをな面に・..故得さ亦を

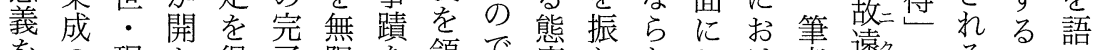

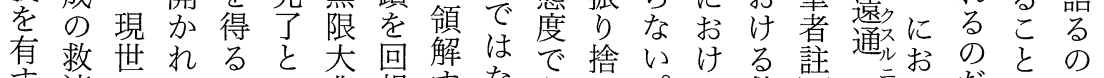

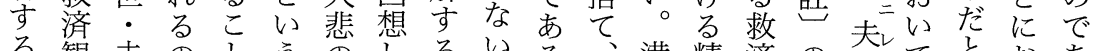

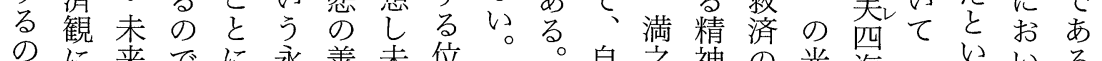

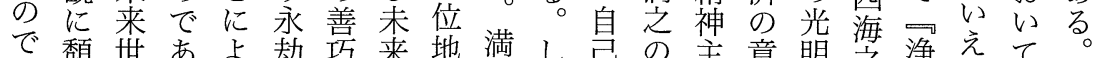

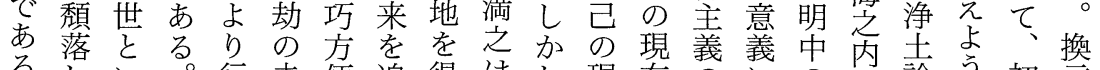
る。しい。行未便追得はし現在のにの皆論方初高 たうそ動来と想爑、在安意加同泉砫加め导

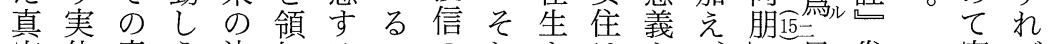
宗体意う決知るののれをはを、兄脊安ば

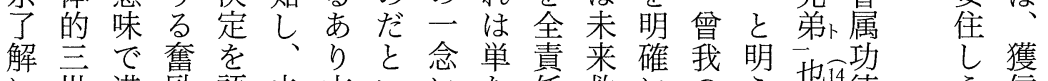

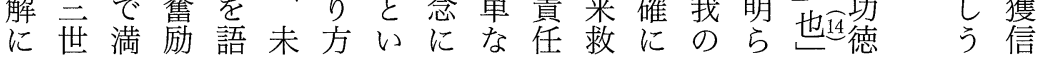

平頁前 10 の無ま衆集二6 得に二活館 法満れ院 1

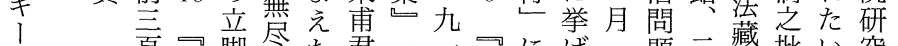

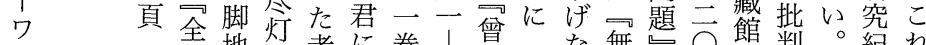

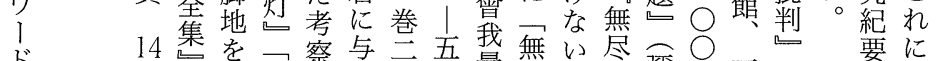

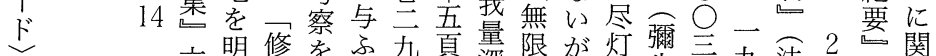

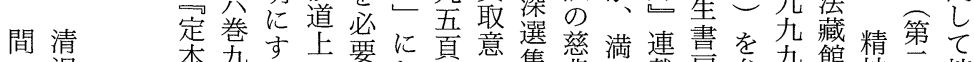
沢本九产の要颃集悲之載房参九館神青拙 満行頁明重すけこ 7 库

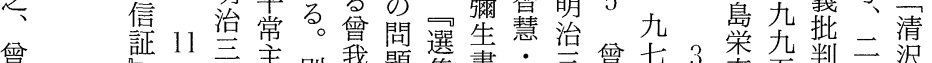

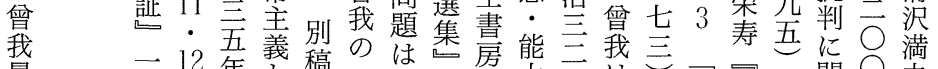

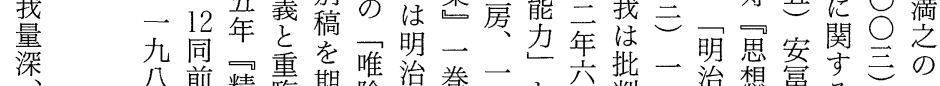
八前精重期唯治巻一七六批二治想䔰す声の

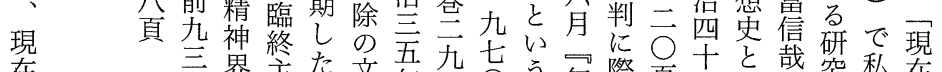
15 頁界主た文年七○う無際頁四し或究私在

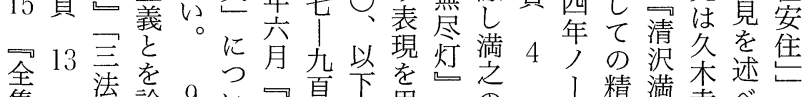

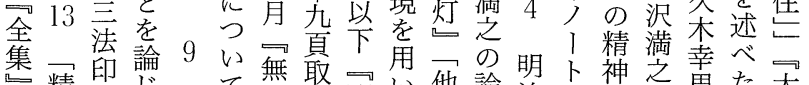

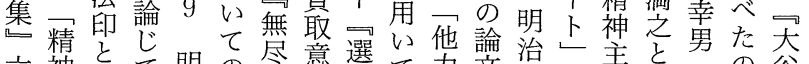
六神唯て明の尽意選て力文治七主と美っの谷 巻主識親治了灯 8 集い信を言宗義個検で美 二義宗變西を解花っ一る。仰具年教思証参学 二同人年踏田選巻発的一死藏想清照大 
it is recorded that concerning the choice of the pilgrimage temples and the way of numbering the temples he inevitably followed the suggestion of $\bar{O}$ saka-kō. Ōsaka-kō was a group of pilgrims and their leader was a merchant from Ōsaka. Ōsaka-kō donated pictures of St. Hōnen and pilgrim songs to the temple, published books of pilgrim songs and erected many memorial stones and signposts. In this way, Ōsaka-kō contributed to the establishment of the twenty-five historical holy places of St. Hōnen's activities and to the development of this pilgrimage.

147. Consciousness of the Sect Name in Nichiren Buddhism: A dispute in Okayama.

Senshō SAKAWA

In the eighth year of Kansei (1896) occurred an incident between the Okayama clan and Nichiren sect temples concerning the name of the sect. The Okayama clan tried to forbid the use of the name Hokeshū as the sect's official name. However, in the face of the objection of Nichiren sect, they gave up their efforts. The Nichiren temple of those days considered the appellation Hokeshū to be extremely important.

148. Kiyozawa Manshi's Genzai-anjū (Peaceful Settlement in the Present Time): Consideration of its aspect of time

Yūsetsu Nishimoto

The purpose of this study is to clarify the aspect of time in Kiyozawa Manshi's Genzai-anjū. In the early part of my study, I refer to the criticism of Soga Ryōjin against Kiyozawa's Seishin-shugi (Spiritual Activism). The main point of the criticism by Soga, in short, is the lack of the practice of compassion and the norm of conduct for the future in Kiyozawa's Genzaianjū.

In the second part of this paper, I consider "Seishinshugi-to-sanze" as Kiyozawa's reply to the criticism of Soga. Kiyozawa responds to this criticism, 
saying that "Seishin-shugi is Akirame-shugi (the resignation attitude) for the past, Seishin-shugi is Anju-shugi (peaceful settlement) in the present, Seishinshugi is Funrei-shugi (doing one's best) for the future." 【KMZ, vol. 6, p.9l】 Besides he insists that the principal aim of the Seishin-shugi is peaceful settlement in the present time. In the course of my argument it should become clear that Kiyozawa insists that compassion does not have meaning for the past and the future but has meaning for the faith in the present moment and that Genzai-anjū realizes release from recollection of the past and the future and that Genzai-anjū results in Akirame-shugi for the past and Funrei-shugi for the future.

\section{Representation and Theory in Buddhist Iconography}

Shunshō MANABE

Considering the representation of Buddhist icons and the theoretical concepts underlying them is important in all topics making up the framework of Buddhist art. Buddhist imagery that was born in India eventually crossed the Himalayas, was carried through Central Asia and into China, and then introduced to Japan via the Korean peninsula. Beginning with Buddha, iconographical drawings sustained the representation of Buddhist art. While many issues such as faith and representation as well as worship and representation arose in India and elsewhere, until now comparative research has been carried out only fragmentarily on the relationship of Buddhist art to scriptures and regulations, and the diverse forms of history and culture have not yet been fully examined.

This study includes an analysis of the Śākyamuni triad, in which the main image is teaching (a situation in which Śākyamuni delivers a sermon, and people gather in front to listen). The form of the triad, with central icon flanked by left and right images, radiates power, and the domain of worship spreads accordingly, achieving a sense of balance. The objects of worship that unfold from this scene give birth to the mandala. Ultimately one becomes aware of a separate object of worship known as Besson Mandara among the multitu- 